CrossMark \& click for updates

Cite this: Metallomics, 2016, 8, 298

Received 21st October 2015, Accepted 22nd December 2015

DOI: $10.1039 / \mathrm{c} 5 \mathrm{mt} 00272 \mathrm{a}$

www.rsc.org/metallomics

\section{Cellular uptake of metallated cobalamins}

\author{
Mai Thanh Quynh Tran, $\dagger^{\mathrm{a}}$ Stefan Stürup, ${ }^{\text {b }}$ Ian Henry Lambert, ${ }^{\mathrm{c}}$ \\ Bente Gammelgaard, ${ }^{b}$ Evelyne Furger $\stackrel{\mathrm{f}}{\mathrm{d}}^{\mathrm{a}}$ and Roger Alberto*a
}

\begin{abstract}
Cellular uptake of vitamin B12-cisplatin conjugates was estimated via detection of their metal constituents (Co, $\mathrm{Pt}$, and Re) by inductively coupled plasma mass spectrometry (ICP-MS). Vitamin B12 (cyano-cob(III)alamin) and aquo-cob(III)alamin $\left[\mathrm{Cbl}-\mathrm{OH}_{2}\right]^{+}$, which differ in the $\beta$-axial ligands $\left(\mathrm{CN}^{-}\right.$and $\mathrm{H}_{2} \mathrm{O}$, respectively), were included as control samples. The results indicated that B12 derivatives delivered cisplatin to both cellular cytosol and nuclei with an efficiency of one third compared to the uptake of free cisplatin cis- $\left[\mathrm{Pt}^{\prime \prime} \mathrm{Cl}_{2}\left(\mathrm{NH}_{3}\right)_{2}\right]$. In addition, uptake of charged B12 derivatives including $\left[\mathrm{Cbl}-\mathrm{OH}_{2}\right]^{+}, \quad\left[\{\mathrm{CO}\}-\mathrm{CN}-\left\{\mathrm{cis}-\mathrm{PtCl}\left(\mathrm{NH}_{3}\right)_{2}\right\}\right]^{+}, \quad\left[\{\mathrm{Re}\}-\{\mathrm{Co}\}-\mathrm{CN}-\left\{\mathrm{Cis}-\mathrm{PtCl}\left(\mathrm{NH}_{3}\right)_{2}\right\}\right]^{+}$, and $\left[\{\mathrm{CO}\}-\mathrm{CN}-\left\{\text { trans-Pt }(\mathrm{Cyt})\left(\mathrm{NH}_{3}\right)_{2}\right\}\right]^{2+}$ (Cyt = cytarabin) was high compared to neutral B12, which implied the existence of an additional internalization pathway for charged B12 vitamin analogs. The affinities of the charged $\mathrm{B} 12$ derivatives to the $\mathrm{B} 12$ transporters $\mathrm{HC}$, IF and TC were similar to that of native vitamin $\mathrm{B} 12$.
\end{abstract}

\section{Introduction}

Cyano-cob(III)alamin, also designated vitamin B12, is an essential, water soluble, and non-toxic vitamin even at high doses. Vitamin B12 is involved in the methionine synthesis and the tricarboxylic acid cycle. B12 comprises an octahedral $\mathrm{Co}^{\mathrm{III}}$ complex with a tetradentate corrin ring, an $\alpha$-nucleotide loop and a $\mathrm{CN}^{-}$ligand in the $\beta$-axial position. The cyanide ligand can be exchanged for other monodentate functions (Fig. 1). ${ }^{1}$ Intracellular reduction of the $\mathrm{Co}^{\mathrm{III}}$ center subsequently forms square pyramidal cob(II)alamin and square planar cob(I)alamin, respectively. ${ }^{2,3}$ Enzymatic alkylation of cob(I)alamin in the cytosol and mitochondria leads to the formation of two B12-coenzymes with methyl and adenosyl as $\beta$-ligands. ${ }^{4,5}$ B12 is protected from degradation inside living systems through its binding to the proteins haptocorrin (HC, present in saliva/ gastric fluids), intrinsic factor (IF, secreted by parietal cells), and transcobalamin (TC, plasma protein). ${ }^{6,7}$ Binding of B12 to TC is required for facilitating the uptake of the B12-TC complex via the TC-receptor or CD320 (across most membranes) and megalin (reabsorbed from the urine in kidney cells). ${ }^{7}$ The B12 specificity follows the order: $\mathrm{IF}>\mathrm{TC} \gg \mathrm{HC}^{8-11}$ Numerous functional groups

\footnotetext{
${ }^{a}$ Institute of Inorganic Chemistry, University of Zürich, Winterthurerstr. 190, 8057 Zürich, Switzerland.E-mail: ariel@aci.uzh.ch

${ }^{b}$ Department of Pharmacy, Faculty of Health Sciences, University of Copenhagen, Universitetsparken 2, 2100 Copenhagen, Denmark.

E-mail: stefan.sturup@sund.ku.dk

${ }^{c}$ Department of Biology, University of Copenhagen, Universitetsparken 13, 2100 Copenhagen, Denmark

${ }^{d}$ Center for Radiopharmaceutical Science, Paul Scherrer Institute, CH-5232 Villigen PSI, Switzerland

$\dagger 13$ Nguyen Tuan Street, Ward 3, Go Vap District, Ho Chi Minh City, Vietnam.

¥ Present address: Therwilerstrasse 47, 4153 Reinach, Switzerland.
}

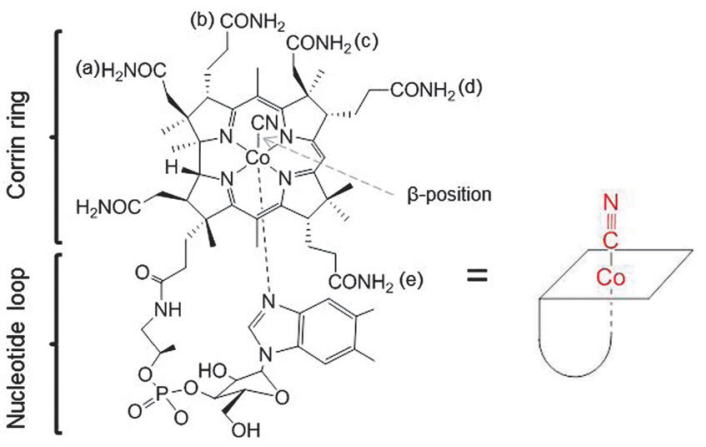

Fig. 1 Structure of Cyano-cob(III)alamin, vitamin B12 (left) and sketch of B12 for the following figures.

on the corrin side chains, $\beta$-ligand, and $\alpha$-nucleotide loop (Fig. 1) are available to coordinate or conjugate drugs and analytical modalities. ${ }^{12}$ The $\beta$-axial ligand is a preferred derivatization site owing to its ease-of-release in cellular environment and its little involvement in interaction with proteins. Nitrogen mustard chlorambucil, ${ }^{13}$ colchicine,${ }^{14}$ cisplatin, ${ }^{15}$ and insulinomimetic vanadate $\left(\mathrm{V}^{\mathrm{V}}\right)$ compound ${ }^{16}$ are drugs which have been bound to $\mathrm{B} 12$ at this site. In addition, fluorophores ${ }^{17}$ and radionuclides ${ }^{18,19}$ have also been attached to B12 at this position. The ribosehydroxyl group is another convenient derivatization site as it is not involved in protein interaction. ${ }^{20}$ Fluorophores, ${ }^{21,22}$ cytotoxic drugs, ${ }^{23}$ insulin, ${ }^{24}$ and appetite suppressing peptide $\mathrm{hPYY}^{25}$ have been coupled to B12 via this position.

Derivatization of B12, however, is not limited to the $\beta$ - and ribose-positions. Radioactive ${ }^{111}$ In-DTPA and ${ }^{99 m}$ Tc-DTPA were coupled to B12 via the b-side chain. ${ }^{26,27}$ The $\left\{{ }^{99 \mathrm{~m}} \mathrm{Tc}(\mathrm{CO})_{3}\right\}$ moiety was coupled to B12 via ligands coupled to the b- and d-side chains ${ }^{28}$ and biotin via either the b-, c-, d-, or e-side 
chains. ${ }^{12}$ Increasing structural knowledge of B12 and of its transport proteins is the base for fine-tuning the structures of biologically active $B_{12}$ derivatives and mimetics. Several $B_{12}$ antagonists were reported, including B12-[c-lactam $],{ }^{29}$ and B12 with de novo peptide backbones. ${ }^{30,31}$ In addition, tissue distribution was interfered by modifying the B12 structure at a critical site (b-side chain) for protein interaction. ${ }^{32}$

Research programs have been dedicated to explore the correlation of B12 requirements and DNA synthesis. This, however, is not the only advantage of using B12 as a carrier for anti-cancer drugs. Its water solubility allows convenient administration of the attached insoluble drugs. ${ }^{15}$ B12 protects protein-peptide drugs ${ }^{24,25,33}$ from hydrolysis in the acidic condition of the gastrointestinal track. ${ }^{34}$ Though the utilization of B12 as drug carrier appeared to be restrained by its cellular loading capacity, ${ }^{35}$ a recent study showed that tissue accumulation of B12 increased significantly (up to $350 \%$ ) upon overdosing of the vitamin. $^{36}$

In this paper, B12 was applied as a drug carrier for cisplatin and as a carrier of the $\left\{\text { fac- } \operatorname{Re}(\mathrm{CO})_{3}\right\}^{+}$moiety, which is a model moiety for Tc and Re radiopharmaceuticals. Cisplatin was chosen as it is the most often used platinum based drug in the clinic, its mode of action is binding to DNA in the nucleus, which triggers apoptosis and cell death. Cisplatin is taken up by the cells via passive diffusion or via active transport through the copper transporters (CTR1 and CTR2) and the organic cation transporters (OCTs) and possible also other pathways. ${ }^{37}$ Once in the cell cisplatin undergoes aquation, chloride exchanged by water, forming positive

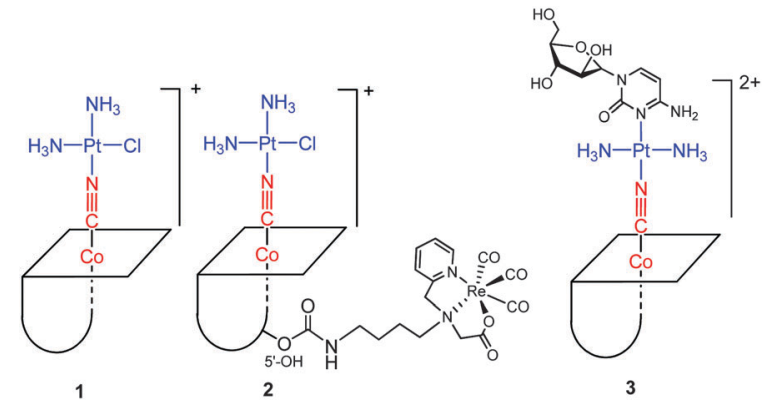

Fig. 2 Structures of $\mathrm{B} 12$ derivatives including $\left[\{\mathrm{Co}\}-\mathrm{CN}-\left\{\mathrm{Cis}-\mathrm{PtCl}\left(\mathrm{NH}_{3}\right)_{2}\right\}\right]^{+}(\mathbf{1})$, $\left[\{\mathrm{Re}\}-\{\mathrm{Co}\}-\mathrm{CN}-\left\{\mathrm{Cis}-\mathrm{PtCl}\left(\mathrm{NH}_{3}\right)_{2}\right\}\right]^{+}(\mathbf{2})$, and $\left[\{\mathrm{CO}\}-\mathrm{CN}-\left\{\text { trans-Pt }(\mathrm{Cyt})\left(\mathrm{NH}_{3}\right)_{2}\right\}\right]^{2+}(\mathbf{3})$. ions which are more reactive towards the main biological target, DNA. ${ }^{38}$ We determined the cytosolic and nucleic uptake of cisplatin, vitamin B12, [\{Co\}-CN- $\left\{\right.$ cis-PtCl $\left.\left.\left(\mathrm{NH}_{3}\right)_{2}\right\}\right]^{+}(\mathbf{1}),[\{\mathrm{Re}\}-\{\mathrm{Co}\}-\mathrm{CN}-\{$ cis$\left.\left.\operatorname{PtCl}\left(\mathrm{NH}_{3}\right)_{2}\right\}\right]^{+}(2)$, and $\left[\{\mathrm{Co}\}-\mathrm{CN}-\left\{\text { trans-Pt }(\mathrm{Cyt})\left(\mathrm{NH}_{3}\right)_{2}\right\}\right]^{2+}$ (3) (Fig. 2) in human leukemia cells (K562 cells) and non-adherent (EATC)/ adherent (ELA) Ehrlich ascites tumor cells. The uptake was determined by ICP-MS, where the contents of Co, Pt, and Re represent the uptake of B12 and the platinum/rhenium drug, respectively.

\section{Results and discussion}

\section{Synthesis of $\left[\{\mathrm{Re}\}-\{\mathrm{Co}\}-\mathrm{CN}-\left\{\text { cis-PtCl}\left(\mathrm{NH}_{3}\right)_{2}\right\}\right]^{+}$}

The tridentate NNO ligand (6) was chelated to the $\left\{\text { fac-Re }(\mathrm{CO})_{3}\right\}^{+}$ moiety prior to conjugation to the B12 structure (step iv and v,), see Scheme 1. In the next step, the $\beta-\mathrm{CN}^{-}$was coordinated to [cis-PtCl $\left.\left(\mathrm{OH}_{2}\right)\left(\mathrm{NH}_{3}\right)_{2}\right]^{+}$by substituting the aquo-ligand bound to $\mathrm{Pt}^{\mathrm{II}}$ (step vi) to yield 2. This synthesis scheme produced a high yield $(80 \%)$ of $\left[\{\mathrm{Re}\}-\{\mathrm{Co}\}-\mathrm{CN}-\left\{\text { cis-PtCl}\left(\mathrm{NH}_{3}\right)_{2}\right\}\right]^{+}$(2, Scheme 1).

The IR stretching frequency of $\mathrm{CN}^{-}$was higher in $2\left(2200 \mathrm{~cm}^{-1}\right)$ than in B12 $\left(2134 \mathrm{~cm}^{-1}\right)$. It confirmed the formation of $\left.\{\mathrm{Co}\}\right\}-\mathrm{CN}$ $\left\{-\{\mathrm{Pt}\}\right.$ coordinative bond in 2 , as it was previously reported that $\mathrm{CN}^{-}$ stretching frequency, bridging two metal centers $(\{\mathbf{M}\}\}-\mathrm{CN}\left\{-\left\{\mathbf{M}^{\prime}\right\}\right)$, appears at higher frequency than terminal $\left.\mathrm{CN}^{-}(\{\mathrm{M}\}\}-\mathrm{CN}\right) \cdot{ }^{15,39}$ The doubly charged species $(\mathrm{m} / \mathrm{z}$ 1076.6) on ESI-MS confirmed the formation of 2 and the NMR spectrum is in agreement with its authenticity. The single signal in the ${ }^{195} \mathrm{Pt}$ NMR spectrum at $-2354 \mathrm{ppm}$ is in the same range as previously reported B12 derivatives containing $\{\mathrm{Co}\}-\mathrm{CN}\left\{-\{\mathrm{Pt}\}\right.$ bonds. ${ }^{15,40}$ Compared to the ${ }^{1} \mathrm{H}$ NMR spectrum of $\left[\{\mathrm{Co}\}-\mathrm{CN}-\left\{\mathrm{PtCl}\left(\mathrm{NH}_{3}\right)_{2}\right\}\right]^{+}$previously published $^{40}$ the spectrum of $\left[\{\mathrm{Re}\}-\{\mathrm{Co}\}-\mathrm{CN}-\left\{\text { cis-PtCl}\left(\mathrm{NH}_{3}\right)_{2}\right\}\right]^{+}$ shows four additional ${ }^{1} \mathrm{H}$ signals (from the Re-[chelate]-ligand) in the fingerprint aromatic region $>5.5 \mathrm{ppm}$ (unmarked peaks in Fig. 3), which further confirmed the presence of the rhenium complex.

\section{Affinity of B12 derivatives towards transport proteins}

Affinity to transport proteins of B12 derivatives was measured by Differential Scanning Fluorometry (DSF), where a fluorescent dye interacts with the hydrophobic sites of unfolded proteins and the melting temperature $\left(T_{\mathrm{m}}\right)$ of proteins can be inferred from the recorded fluorescence intensity. ${ }^{41,42}$ Following ligand

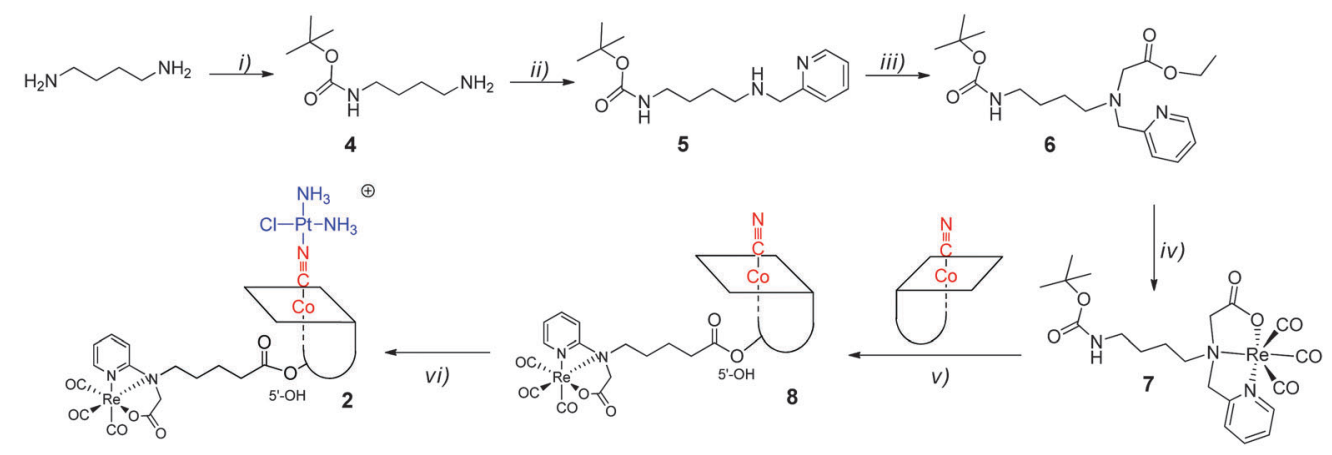

Scheme 1 Synthesis scheme towards $\left[\{\mathrm{Re}\}-\{\mathrm{Co}\}-\mathrm{CN}-\left\{\mathrm{cis}-\mathrm{PtCl}\left(\mathrm{NH}_{3}\right)_{2}\right\}\right]^{+}$(2): (i) $\mathrm{Boc}_{2} \mathrm{O}$; (ii) py-2-CHO, $\mathrm{NaBH}_{4}$; (iii) $\mathrm{BrCH}_{2} \mathrm{CO}_{2} \mathrm{Et}$; (iv) $\left[\mathrm{NEt}_{4}\right]_{2}\left[\mathrm{ReBr}{ }_{3}(\mathrm{CO})_{3}\right]$; (v) TFA and then CDT, TEA; (vi) cisplatin, $\mathrm{AgNO}_{3}$ 


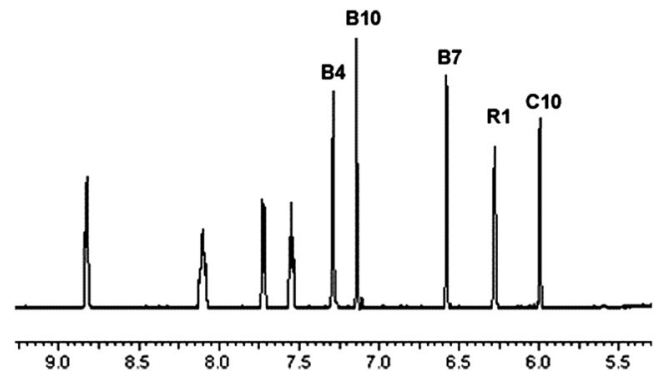

Fig. $3{ }^{1} \mathrm{H}$ NMR spectrum of $\left[\{\mathrm{Re}\}-\{\mathrm{Co}\}-\mathrm{CN}-\left\{\mathrm{cis}-\mathrm{PtCl}\left(\mathrm{NH}_{3}\right)_{2}\right\}\right]^{+}$(2).

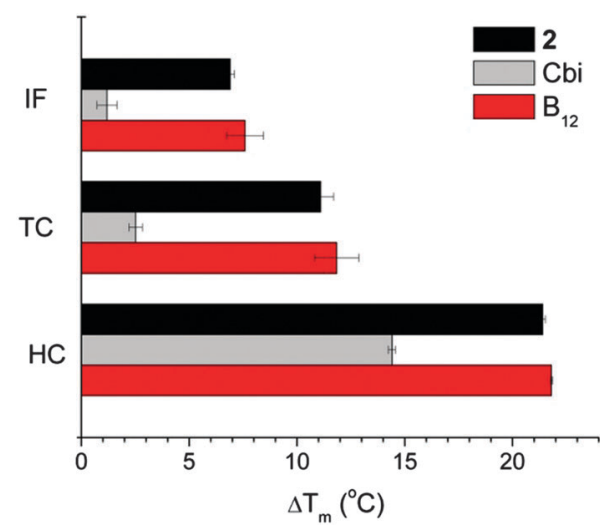

Fig. 4 Binding of $\mathrm{B} 12$ and $\left[\{\mathrm{Re}\}-\{\mathrm{Co}\}-\mathrm{CN}-\left\{\mathrm{Cis}-\mathrm{PtCl}\left(\mathrm{NH}_{3}\right)_{2}\right\}\right]^{+}$(2) to haptocorrin $(\mathrm{HC})$, intrinsic factor (IF), and transcobalamin (TC) determined by differential scanning fluorometry. High $\Delta T_{\mathrm{m}}$ values indicate strong binding.

binding, the protein stability is enhanced and the ligand-bound proteins unfold at higher temperature with respect to the free proteins. B12 derivatives which bind to B12 transport proteins would produce comparable $\Delta T_{\mathrm{m}}$ values to those of B12 while $\Delta T_{\mathrm{m}}$ values would be much lower if these derivatives do not bind to B12 transport proteins. In Fig. 4, B12 was used as a positive control for the three transport proteins and cobinamide (Cbi) was used as a negative control. ${ }^{42}$ Despite the chemical modification of the B12 structure, compound 2 retained good affinity to all B12 transport proteins as it has comparable $\Delta T_{\mathrm{m}}$ values to those of B12.
Cellular uptake of $\left[\{\mathrm{Co}\}-\mathrm{CN}-\left\{\text { cis-PtCl}\left(\mathrm{NH}_{3}\right)_{2}\right\}\right]^{+},[\{\mathrm{Re}\}-\{\mathrm{Co}\}-\mathrm{CN}-$ $\left\{\right.$ cis-PtCl$\left.\left.\left(\mathrm{NH}_{3}\right)_{2}\right\}\right]^{+}$and $\left[\{\mathrm{Co}\}-\mathrm{CN}-\left\{\text { trans-Pt }(\mathrm{Cyt})\left(\mathrm{NH}_{3}\right)_{2}\right\}\right]^{2+}$

To obtain information on the action of these compounds, knowledge on the amount of drug taken up by cells and accumulated in the nucleus with and without B12 is required and is the base for evaluating the efficiency of B12 as a tumor-targeting drug carrier molecule. The metals (Co, Re, Pt) in B12-drugs conjugates can be measured by ICP-MS, i.e., cytosolic and nucleic determination of ${ }^{59} \mathrm{Co},{ }^{195} \mathrm{Pt}$, and ${ }^{187} \mathrm{Re}$ reveal the intracellular distribution of these compounds. Fig. 5A shows the cellular cisplatin uptake in K562 cells, determined as the content in the cytosol. The uptake of platinum containing B12 derivatives $(\mathbf{1}, \mathbf{2}$, and $\mathbf{3})$ is approximately one third compared to the uptake of cisplatin. Similarly it is seen from Fig. 5B that the platinum uptake into cellular nuclei of 1, 2, and 3 was low compared to cisplatin. The low nucleic platinum uptake of 3 was expected as it has a transplatin-based structure. ${ }^{43,44}$ More interestingly, substantial extracellular Pt-release from the B12 structures, which would have resulted in comparative cellular uptake to cisplatin, was not observed. These data indicate that Pt is not released in the extracellular media but taken up together with B12. The complexes are protected when conjugated to the B12 structure. Unexpectedly, the cytosolic uptake of B12 was considerably lower than of $\left[\mathrm{Cbl}-\mathrm{OH}_{2}\right]^{+}, \mathbf{1}, \mathbf{2}$, and 3 (Fig. 5). This indicated that the observed uptake was not mediated by TC as this protein has similar affinities to B12, 2 (Fig. 4), and $3 .^{42}$ Therefore TC would have allowed similar accumulation of these compounds in cellular components.

It was previously reported that B12 derivatives are able to enter cells without the support of TC. This uptake was, nevertheless, less efficient. ${ }^{4-48}$ HeLa cells internalized only 1-2\% of free B12 with respect to holo-TC. ${ }^{45}$ It was later concluded that free B12 supported cell growth $\mathrm{ca} .100$ to 1000 -fold less efficiently than holo-TC. ${ }^{49}$ However, human skin fibroblasts could internalize free $\mathrm{B} 12$ better than holo-TC, up to more than $20 \%$ were reported. ${ }^{46}$ Berliner et al. proposed a free B12-specific receptor on the cell membrane ${ }^{46}$ while Hitzig et al. suggested an $\alpha 2$-globulinlike protein in serum as the alternative pathway for cell to internalize free B12 derivatives. ${ }^{50}$

In this study, we observed higher accumulation of $\left[\mathrm{Cbl}-\mathrm{OH}_{2}\right]^{+}$as compared to B12. In a previous report, it was found that $\left[\mathrm{Cbl}-\mathrm{OH}_{2}\right]^{+}$ was internalized and retained better than B12 in human skin
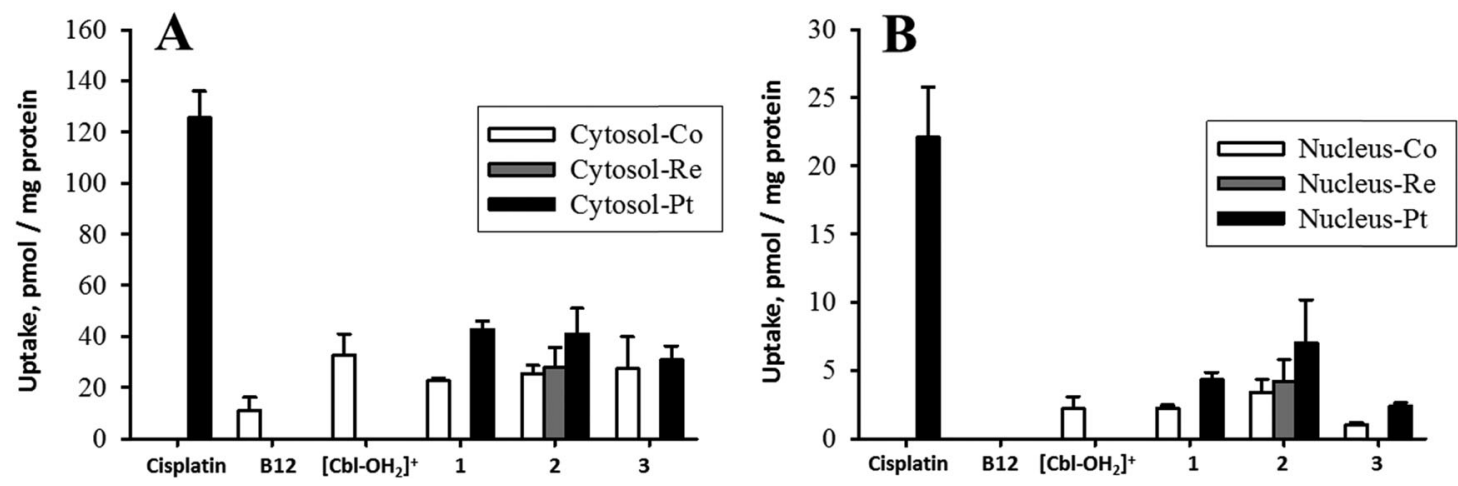

Fig. 5 Uptake in $\mathrm{K} 562$ cellular cytosol (A) and nucleus (B) of $\left[\{\mathrm{Co}\}-\mathrm{CN}-\left\{\mathrm{Cis}-\mathrm{PtCl}\left(\mathrm{NH}_{3}\right)_{2}\right\}\right]^{+}(\mathbf{1}),\left[\{\mathrm{Re}\}-\{\mathrm{Co}\}-\mathrm{CN}-\left\{\mathrm{Cis}-\mathrm{PtCl}(\mathrm{NH})_{2}\right\}\right]^{+}(\mathbf{2})$, and $[\{\mathrm{CO}\}-\mathrm{CN}-\{\operatorname{trans}-$ $\left.\left.\mathrm{Pt}(\mathrm{Cyt})\left(\mathrm{NH}_{3}\right)_{2}\right\}\right]^{2+}(3)$. Cisplatin, $\mathrm{B} 12,\left[\mathrm{Cbl}-\mathrm{OH}_{2}\right]^{+}$were included as control samples. 

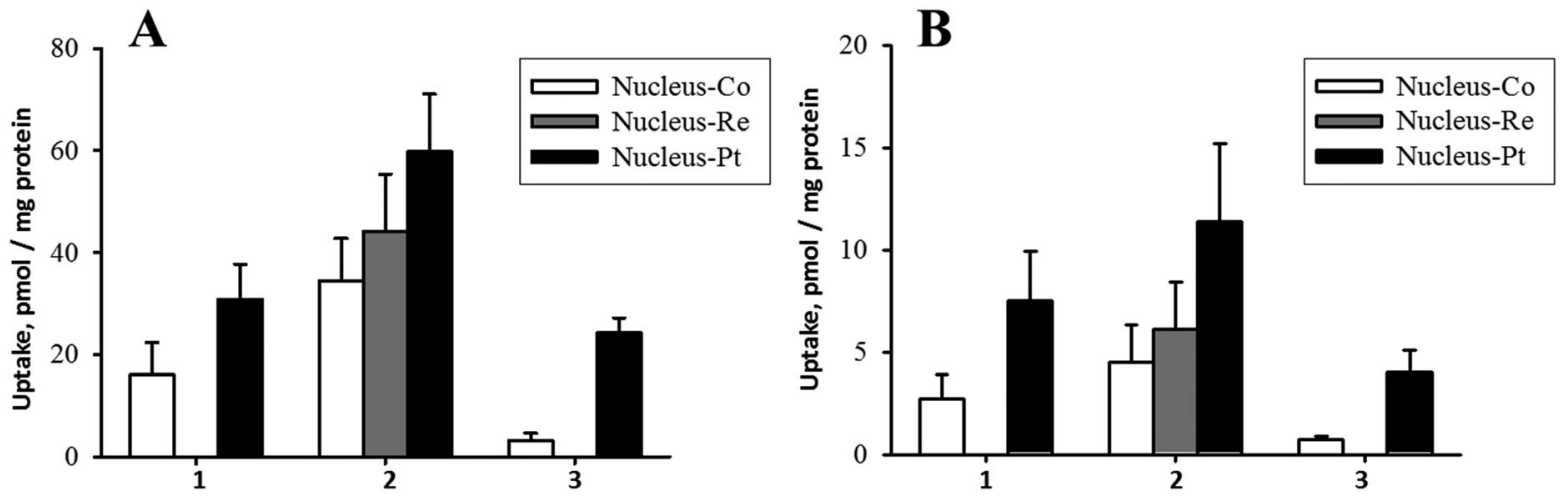

Fig. 6 Nuclear uptake of $\left[\{\mathrm{Co}\}-\mathrm{CN}-\left\{\mathrm{cis}-\mathrm{PtCl}\left(\mathrm{NH}_{3}\right)_{2}\right\}\right]^{+}(\mathbf{1})$, $\left[\{\mathrm{Re}\}-\{\mathrm{Co}\}-\mathrm{CN}-\left\{\mathrm{cis}-\mathrm{PtCl}\left(\mathrm{NH}_{3}\right)_{2}\right\}\right]^{+}(\mathbf{2})$, and $\left.\left[\{\mathrm{Co}\}-\mathrm{CN}-\left\{\text { trans-Pt }(\mathrm{Cyt})(\mathrm{NH})_{3}\right)_{2}\right\}\right]^{2+}(\mathbf{3})$ in non-adherent Ehrlich cells (EATC) and adherent Ehrlich Lettre cells (ELA). Uptake was determined as Co, Re, and Pt content in EATC (A) and ELA (B) measured by ICPMS.

fibroblasts culture ${ }^{51}$ but the root of this difference was not fully understood. As we also found comparable cellular uptake among compounds $1,2,3$, and $\left[\mathrm{Cbl}_{-}-\mathrm{OH}_{2}\right]^{+}$, we conclude that the positive charge carried by these compounds allows cells to internalize them better than the neutral B12 derivatives (Fig. 5). Behavioral differences between charged and neutral B12 derivatives were also previously observed. ${ }^{52}$ It is possible that charged B12 compounds were either distinctly recognized by a B12-specific receptor or they simply passed through the cationic channels on cell membranes. This, however, requires further clarification. In any case, the experimental results highlighted once more the complex multichannel uptake pathways of B12 vitamin analogues including internalization of holo-TC, free B12 derivatives, and charged B12 derivatives. The preferable cellular import of charged B12 compounds should be kept in perspective for future design of pharmaceutical B12 derivatives.

Drugs like cisplatin and cytarabine attached to the $\beta-\mathrm{CN}^{-}$of $\mathrm{B} 12$ are released by reducing enzymes in the cytosol. ${ }^{15,40,42}$ Furthermore, subsequent cytotoxic activities of the released drugs from $\left[\{\mathrm{Co}\}-\mathrm{CN}-\left\{c i s-\mathrm{PtCl}\left(\mathrm{NH}_{3}\right)_{2}\right\}\right]^{+}(\mathbf{1})$ and $[\{\mathrm{Co}\}-\mathrm{CN}-\{$ trans$\left.\left.\mathrm{Pt}(\mathrm{Cyt})\left(\mathrm{NH}_{3}\right)_{2}\right\}\right]^{2+}$ (3) were also demonstrated. ${ }^{42,52}$ Cisplatin interferes with cell division by binding to DNA. Previous studies demonstrated accumulation of cisplatin in the cytosol and the nucleus in non-adherent EATC and adherent ELA cells. ${ }^{53}$ It is therefore especially important for compound $\mathbf{1}$ and $\mathbf{2}$ to deliver platinum to nucleus for DNA interaction. As evident from Fig. 6, platinum accumulated in the nucleus in EATC and in ELA cells similar to K562 cells. Furthermore, we found that the absolute amount of platinum bound to DNA in cells exposed for 18 hours to $10 \mu \mathrm{M}$ and $50 \mu \mathrm{M}\left[\{\mathrm{Re}\}-\{\mathrm{Co}\}-\mathrm{CN}-\left\{c i s-\mathrm{PtCl}\left(\mathrm{NH}_{3}\right)_{2}\right\}\right]^{+}$

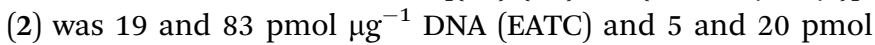
$\mu \mathrm{g}^{-1}$ DNA (ELA). Hence, cisplatin coupled to B12 derivative did accumulate in the nucleus and was bound to DNA.

The uptake of Pt into cellular components was always higher than Co (Fig. 5 and 6). A correlation between cobalt and platinum uptake for the three compounds $\mathbf{1}, \mathbf{2}$ and $\mathbf{3}$ is shown in Fig. 7. The equation for the trend line is $y=1.60 X+4.9$. The one outlier point for EATC, cytosol was omitted. The correlation shows that platinum is taken up by a factor of 1.6 higher than cobalt as estimated from the cytosolic and nucleic content.

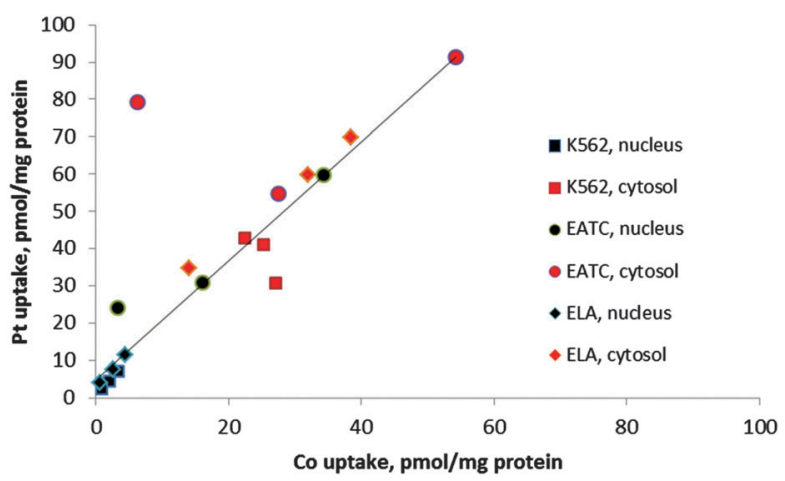

Fig. 7 Correlation between drug (Pt) and vitamin B12 (Co) in K562, EATC, and ELA cells. Uptake was determined as the nuclear (black symbols) and cytosolic (red symbols) Pt and Co content measured by ICPMS.

This observation could reflect a more efficient efflux of Co as compared to platinum.

\section{Conclusions}

We reported here comparable uptake in cellular nuclei and cytosol of different B12-drug conjugates, including $\left[\{\mathrm{Co}\}-\mathrm{CN}-\left\{c i s-\mathrm{PtCl}\left(\mathrm{NH}_{3}\right)_{2}\right\}\right]^{+}$, $\left[\{\mathrm{Re}\}-\{\mathrm{Co}\}-\mathrm{CN}-\left\{\text { cis-PtCl}\left(\mathrm{NH}_{3}\right)_{2}\right\}\right]^{+}$, and $[\{\mathrm{Co}\}-\mathrm{CN}-\{$ trans-Pt(Cyt)$\left.\left.\left(\mathrm{NH}_{3}\right)_{2}\right\}\right]^{2+}$. The results underline that these B12 derivatives deliver cispaltin and cisplatin-related drugs to both, cytosol and nuclei, in two different cancer cell lines. It was found that charged B12 derivatives were preferentially taken up into cellular compartments as compared to neutral and native B12. We therefore propose the existence of an additional uptake pathway for charged B12 derivatives in addition to the previously known TC-mediated B12 uptake pathway. Accumulation of released platinum in the nucleus was clearly observed and explains the cytotoxic action of these compounds as previously described. ${ }^{50}$

\section{Experimental}

\section{Materials and methods}

Analytical high performance liquid chromatography (HPLC) analyses were performed using a Merck-Hitachi L-7000 system 
equipped with a diode-array UV/Vis spectrometer. Reaction progresses to 2, 3, 7 and 8 were monitored by HPLC. Preparative HPLC purification was performed on Varian Prostar system with two Prostar 215 pumps and a Prostar 320 UV/Vis detector. Reaction progresses to 4, 5, and 6 were assessed by TLC. After purification the B12 derivatives were liophilized. Purity was assessed by analytical HPLC, IR, ESI-MS (Bruker Daltonic) and NMR. NMR spectra were recorded by Bruker DRX $500 \mathrm{MHz}$ spectrometer. Chemical shifts are reported relative to residual solvent protons and carbons. The chemical shifts of ${ }^{195} \mathrm{Pt}$ NMR spectra were relative to $\mathrm{Na}_{2} \mathrm{PtCl}_{6}$ in $\mathrm{D}_{2} \mathrm{O}$.

Phosphate-buffered saline (PBS) contained $137 \mathrm{mM} \mathrm{NaCl}$, $2.6 \mathrm{mM} \mathrm{KCl}, 6.5 \mathrm{mM} \mathrm{Na} \mathrm{HPO}_{4}$, and $1.5 \mathrm{mM} \mathrm{KH}_{2} \mathrm{PO}_{4}$. Lysis buffer was prepared from $150 \mathrm{mM} \mathrm{NaCl}, 20 \mathrm{mM}$ HEPES buffer, $1 \mathrm{mM}$ EDTA, 0.5\% Triton X-100 (Pharmacia Biotech AB), $1 \%$ protease inhibitor cocktail (freshly added), $1 \mathrm{mM} \mathrm{NaVO}_{3}$ (freshly added). All aqueous solutions for ICPMS measurement were prepared in purified water $(>18.2 \mathrm{M} \Omega)$ from Milli-Q deionization unit. Standards and samples were prepared in a mixture of $\mathrm{HNO}_{3} 0.65 \%$ : $\mathrm{HCl} 0.1 \%$.

HPLC conditions. The analytical HPLC column was Macherey Nagel Nucleosil C18 (5 $\mu \mathrm{m}, 100 \AA ̊ 2,250 \mathrm{~mm} \times 3 \mathrm{~mm})$. The preparative HPLC column was Macherey Nagel Nucleosil C18 (7 $\mu \mathrm{m}$, $100 \AA, 250 \mathrm{~mm} \times 40 \mathrm{~mm}$ ) with a flow rate of $35 \mathrm{ml}$ per minute. The following solvent system was used: $0.1 \%$ trifluoroacetic acid (TFA) (solvent A), methanol $(\mathrm{MeOH})$ (solvent B). The following solvent gradient was used: gradient 1, 0-5 minutes: 75\% A, 5-30 minutes: $0 \% \mathrm{~A}$.

\section{Syntheses}

$N$-tert-Butyloxycarbonyldiamines $(4))^{54}\left[\mathrm{NEt}_{4}\right]_{2}\left[\operatorname{ReBr}_{3}(\mathrm{CO})_{3}\right],^{55}$ and $\left[\{\mathrm{Co}\}-\mathrm{CN}-\left\{\text { trans-Pt }(\mathrm{Cyt})\left(\mathrm{NH}_{3}\right)_{2}\right\}\right]^{2+}(3)^{42}$ were prepared according to literature procedures. Compounds (5) and (6) were prepared as described in literature ${ }^{56}$ but with the following modifications: $2 \mathrm{~g}$ (4) $(11 \mathrm{mmol})$ was dissolved in $100 \mathrm{ml} \mathrm{MeOH} .1 .3 \mathrm{~g}$ pyridine-2carbaldehyde $(12 \mathrm{mmol})$ was added dropwise. After stirring for 3 hours at room temperature, the solvent was removed and the imine dissolved in $50 \mathrm{ml}$ ethanol (EtOH). Reduction with $1.5 \mathrm{~g}$ $\mathrm{NaBH}_{4}$ in $2 \mathrm{~h}$, removal of solvent, re-dissolution in diluted $\mathrm{NaHCO}_{3}$ and extraction into $\mathrm{CH}_{2} \mathrm{Cl}_{2}$ gave the raw product. The purification of $\mathbf{5}$ was performed with silicagel column (ethylacetate, methanol 1:3) (2.8 g, 91\%). ${ }^{1} \mathrm{H}-\mathrm{NMR}(200 \mathrm{MHz}, \mathrm{MeOD}, \delta$ in ppm): $\delta=8.63(\mathrm{~m}, 1 \mathrm{H}), 7.87(\mathrm{~m}, 1 \mathrm{H}), 7.49(\mathrm{~m}, 1 \mathrm{H}), 7.41(\mathrm{~m}, 1 \mathrm{H})$, $4.37(\mathrm{~s}, 2 \mathrm{H}), 3.32(\mathrm{~m}, 2 \mathrm{H}), 3.29(\mathrm{~m}, 2 \mathrm{H}), 1.94-1.42(\mathrm{~m}, 13 \mathrm{H})$. $R_{\mathrm{f}}=0.28\left(\mathrm{NH}_{4} \mathrm{OH} /\right.$ methanol/ethylacetate, $\left.1: 10: 89\right)$. ESI-MS: $m / z=302.3[\mathrm{M}+\mathrm{H}+\mathrm{Na}]^{2+} \cdot 1.5 \mathrm{~g}(5)$ was mixed with $1 \mathrm{ml}$ triethylamine in $50 \mathrm{ml} \mathrm{EtOH}$. The mixture was cooled to $0{ }^{\circ} \mathrm{C}$. $600 \mu \mathrm{l}$ bromo-acetic acid ethylester was added dropwise within 5 min. After stirring for 30 minutes at $0{ }^{\circ} \mathrm{C}$ and 16 hours at room temperature, the solvent was removed in vacuo. The residue was dissolved in $\mathrm{CH}_{2} \mathrm{Cl}_{2}$. Extraction was performed with $\mathrm{H}_{2} \mathrm{O}$. The organic phase was dried over $\mathrm{MgSO}_{4}$, filtered and the solvent was removed. The product (6) (1.2 g, 60\%) was collected as oil. ${ }^{1} \mathrm{H}-\mathrm{NMR}$ (200 MHz, MeOD, $\delta$ in ppm): $\delta=8.51(\mathrm{~m}, 1 \mathrm{H}), 7.63$ $(\mathrm{m}, 1 \mathrm{H}), 7.47$ (d, J = 7.8 Hz, 1H), $7.13(\mathrm{~m}, 1 \mathrm{H}), 4.73(\mathrm{~m}, 1 \mathrm{H})$, 4.13 (q, $J=7.2,7,7.2 \mathrm{~Hz}, 2 \mathrm{H}), 3,89(\mathrm{~s}, 2 \mathrm{H}), 3.36(\mathrm{~s}, 2 \mathrm{H}), 3.06$ $(\mathrm{d}, J=6 \mathrm{~Hz}, 2 \mathrm{H}), 2.65(\mathrm{t}, J=6.6,6.8 \mathrm{~Hz}, 2 \mathrm{H}), 2.61-1.20(\mathrm{~m}, 15 \mathrm{H})$. ESI-MS: $m / z=366.3[\mathrm{M}+\mathrm{H}]^{+}$.

4-\{Tricarbonylrhenium(I)-[(N,N,O)-(aceticacid)-(pyridine-2ylmethyl)amino]\} butylcarbamic acid tert-butyl ester (7). $60 \mathrm{mg}$ (1.5 mmol) $\mathrm{NaOH}$ in $1 \mathrm{ml} \mathrm{H}_{2} \mathrm{O}$ was added to a solution of $176.2 \mathrm{mg}(0.48 \mathrm{mmol})$ of $(6)$ in $2.5 \mathrm{ml} \mathrm{MeOH}$. The reaction was stirred overnight. The $\mathrm{pH}$ was adjusted to 7 with $2 \mathrm{M} \mathrm{HCl}$ and buffered with saturated $\mathrm{NaHCO}_{3} .374 \mathrm{mg}(0.48 \mathrm{mmol})$ $\left[\mathrm{NEt}_{4}\right]_{2}\left[\mathrm{ReBr}_{3}(\mathrm{CO})_{3}\right]$ in $7 \mathrm{ml} \mathrm{MeOH}$ was added. The mixture was refluxed at $60{ }^{\circ} \mathrm{C}$ for $4 \mathrm{~h}$. The product 7 was washed with water to remove residual $\mathrm{NEt}_{4} \mathrm{Br}$ to receive the pure product (235 mg, 80\%). ${ }^{1} \mathrm{H}-\mathrm{NMR}$ (500 MHz, $\mathrm{CD}_{3} \mathrm{CN}, \delta$ in ppm): $\delta=8.77$ $(\mathrm{d}, J=5.5 \mathrm{~Hz}, 1 \mathrm{H}), 8.02(\mathrm{t}, J=8.5 \mathrm{~Hz}, 1 \mathrm{H}), 7.59(\mathrm{~d}, J=8 \mathrm{~Hz}, 1 \mathrm{H})$, $7.47(\mathrm{t}, J=6.5 \mathrm{~Hz}, 1 \mathrm{H}), 5.33(\mathrm{~s}, 1 \mathrm{H}), 4.57$ (d, $J=16 \mathrm{~Hz}, 1 \mathrm{H}), 4.40$ (d, $J=15.5 \mathrm{~Hz}, 1 \mathrm{H}), 3.70(\mathrm{~d}, J=18 \mathrm{~Hz}, 1 \mathrm{H}), 3.56(\mathrm{~m}, 2 \mathrm{H}), 3.32$ (d, $J=17 \mathrm{~Hz}, 1 \mathrm{H}), 3.08(\mathrm{~m}, 2 \mathrm{H}), 1.81(\mathrm{~m}, 2 \mathrm{H}), 1.48(\mathrm{~m}, 2 \mathrm{H})$, 1.4 (s, 13H). IR (KBr, cm $\left.{ }^{-1}\right)$ : 2018, 1889, 1872 (CO). ESI-MS: $m / z=630.3[\mathrm{M}+\mathrm{Na}]^{+}$.

Synthesis of (8). $50 \mathrm{mg}(82.5 \mu \mathrm{mol})$ of (7) was Boc deprotected with $1 \mathrm{ml}$ TFA in $3 \mathrm{ml} \mathrm{CH}_{2} \mathrm{Cl}_{2}$. To a solution of $150 \mathrm{mg}$ $(0.11 \mathrm{mmol}) \mathrm{B} 12$ in $3.5 \mathrm{ml}$ dry DMSO was added $24 \mathrm{mg}$ (0.15 mmol) CDT. The mixture was stirred for $1 \mathrm{~h}$ at $60{ }^{\circ} \mathrm{C}$. Then the Boc-deprotected product was added together with $4 \mathrm{ml}$ dry DMSO and $0.8 \mathrm{ml}$ triethylamine. The reaction was stirred overnight. Diethyl ether was added to precipitate the product. Separation of (8) was performed on preparative HPLC, solvent system 1, gradient 1 (31 mg, 14.5\%). ${ }^{1} \mathrm{H}-\mathrm{NMR}$ (500 MHz, MeOD, $\delta$ in ppm): $\delta=8.81(\mathrm{~d}, J=5.5 \mathrm{~Hz}, 1 \mathrm{H}), 8.07(\mathrm{~m}, 1 \mathrm{H}), 7.71(\mathrm{t}, J=6.5 \mathrm{~Hz}$, $1 \mathrm{H}), 7.52(\mathrm{~m}, 1 \mathrm{H}), 7.25$ (s, 1H), 7.13 (d, $J=4 \mathrm{~Hz}, 1 \mathrm{H}), 6.57$ (s, 1H), 6.24 (s, 1H), 5.97 (s, 1H). IR (KBr, cm ${ }^{-1}$ ): 2136 (CN); 2028, 1918, 1902 (CO). ESI-MS: $m / z=1888[\mathrm{M}+\mathrm{H}]^{+}, 945[\mathrm{M}+2 \mathrm{H}]^{2+}$.

Synthesis of (2). $12 \mathrm{mg}(40 \mu \mathrm{mol})$ of cisplatin and $6.7 \mathrm{mg}$ $(39 \mu \mathrm{mol})$ of $\mathrm{AgNO}_{3}$ were mixed in $1 \mathrm{ml} \mathrm{H}_{2} \mathrm{O}$. The reaction was stirred in the absence of light at $40{ }^{\circ} \mathrm{C}$ for $4 \mathrm{~h}$. $\mathrm{AgCl}$ was filtered and the filtrate was added to $22 \mathrm{mg}(11.6 \mu \mathrm{mol})$ of $(8)$. The reaction was stirred at $45{ }^{\circ} \mathrm{C}$ for one day in the absence of light. The product was purified by preparative HPLC, solvent system 1, gradient 1 (20 mg, 80\%). ${ }^{1} \mathrm{H}-\mathrm{NMR}(500 \mathrm{MHz}, \mathrm{MeOD}, \delta$ in ppm): $\delta=8.80(\mathrm{~d}, J=5 \mathrm{~Hz}, 1 \mathrm{H}), 8.08(\mathrm{~d}, J=6 \mathrm{~Hz}, 1 \mathrm{H}), 7.72$ $(\mathrm{m}, 1 \mathrm{H}), 7.54(\mathrm{~m}, 1 \mathrm{H}), 7.25(\mathrm{~s}, 1 \mathrm{H}), 7.14(\mathrm{~s}, 1 \mathrm{H}), 6.58(\mathrm{~s}, 1 \mathrm{H}), 6.26$ (s, 1H), 5.99 (s, 1H). ${ }^{195} \mathrm{Pt}-\mathrm{NMR}$ (107 MHz, MeOD, $\delta$ in ppm): $\delta=-2354$. IR (KBr, cm ${ }^{-1}$ ): $2200(\mathrm{CN}) ; 2026,1916,1904$ (CO). ESI-MS: $m / z=1076.6[\mathrm{M}+2 \mathrm{H}]^{2+}$.

\section{Affinity to transport proteins}

Binding to HC/IF and TC was measured by differential scanning fluorimetry (DSF). Details of the method, protein expression and purification was previously described. ${ }^{42}$

Uptake measurement with ICPMS. Cells were seeded in T-75 flasks with a seeding density of $3 \times 10^{6}$ cells per flask. The culture medium was $12 \mathrm{ml}$ Roswell Park Memorial Institute (RPMI)-1640 with 10\% fetal bovine serum (FCS) and penicillinstreptomycin $\left(100 \mathrm{U} \mathrm{ml}^{-1}\right)$. After 1 day of incubation, each flask was treated with $10 \mu \mathrm{M}$ of a compound. These included cisplatin, $\mathrm{B}_{12},\left[\mathrm{Cbl}-\mathrm{OH}_{2}\right]^{+},(\mathbf{1}),(2)$, and (3). Cells were further maintained in culture for two days. Nucleic and cytosolic 
fractions were separated according to a previously published procedure with certain modifications. ${ }^{53}$ In details, cells were centrifuged for 1 minute at $700 \mathrm{~g}$ and room temperature (adherent ELA cells were trypsinized with $0.25 \%$ trypsine/EDTA in PBS before this step). The supernatant was discarded. Pellets were washed $(3 \times)$ with $5 \mathrm{ml}$ PBS before chemical lysis. ${ }^{57}$ Lysis buffer was added. $20 \mu$ of the lysate was spared for protein determination (DC Protein Assay, Bio-Rad). Remaining lysate was centrifuged at $600 \mathrm{~g}, 4{ }^{\circ} \mathrm{C}$ for 5 minutes. The pellet was washed $(3 \times)$ with $1 \mathrm{ml}$ $\mathrm{NaCl} / \mathrm{KCl}(30 \mathrm{mM} / 120 \mathrm{mM})$ solution to isolate nuclei fraction. The supernatant was centrifuged at $5500 \mathrm{~g}, 4{ }^{\circ} \mathrm{C}$ for 15 minutes. Cytosolic fraction was the supernatant part. The nuclei fractions were digested with $100 \mu \mathrm{l}$ concentrated $\mathrm{HNO}_{3}$.

DNA was isolated according to the following procedure. Cells were centrifuged two times for $5 \mathrm{~s}$ at 13000-16000 g. The precipitate was subsequently lysed with $300 \mu$ lysis solution. $100 \mu \mathrm{l}$ of Protein Precipitation Solution was added and mixed well. After the proteins were precipitated, the supernatant was transferred into isopropanol $(300 \mu \mathrm{l})$. This mix is centrifuged for 1 minute at 13000-16000 $g$ to collect DNA as precipitate. The DNA fractions were washed with $70 \%$ ethanol. DNA hydration solution $(50 \mu \mathrm{l})$ was then added to the dry DNA. The mixture was then incubated in a water bath at $65{ }^{\circ} \mathrm{C}$ for 1 hour to dissolve DNA, followed by incubating at room temperature overnight. Both subcellular fractions were diluted with $0.65 \% \mathrm{HNO}_{3} / 0.1 \% \mathrm{HCl}$ for ICPMS measurement.

\section{Acknowledgements}

Financial support by the University of Zürich and the Chemical and Molecular Science Graduate School CMSZH is gratefully acknowledged. COST action CM1105 is acknowledged for their support.

\section{References}

1 L. Randaccio, S. Geremia, G. Nardin and J. Wuerges, Coord. Chem. Rev., 2006, 250, 1332-1350.

2 M. D. Wirt, I. Sagi, E. Chen, S. M. Frisbie, R. Lee and M. R. Chance, J. Am. Chem. Soc., 1991, 113, 5299-5304.

3 M. D. Wirt, I. Sagi and M. R. Chance, Biophys. J., 1992, 63, 412-417.

4 G. A. Walker, S. Murphy and F. M. Huennekens, Arch. Biochem. Biophys., 1969, 134, 95-102.

5 M. V. Fonseca and J. C. Escalante-Semerena, J. Biol. Chem., 2001, 276, 32101-32108.

6 S. N. Fedosov, Subcell. Biochem., 2012, 56, 347-367.

7 M. J. Nielsen, M. R. Rasmussen, C. B. Andersen, E. Nexø and S. K. Moestrup, Nat. Rev. Gastroenterol. Hepatol., 2012, 9, 345-354.

8 J. F. Kolhouse and R. H. Allen, J. Clin. Invest., 1977, 60, 1381-1392.

9 E. Stupperich and E. Nexø, Eur. J. Biochem., 1991, 199, 299-303.

10 S. N. Fedosov, N. U. Fedosova, B. Kräutler, E. Nexø and T. E. Petersen, Biochemistry, 2007, 46, 6446-6458.
11 J. Wuerges, S. Geremia and L. Randaccio, Biochem. J., 2007, 403, 431-440.

12 P. M. Pathare, D. S. Wilbur, S. Heusser, E. V. Quadros, P. McLoughlin and A. C. Morgan, Bioconjugate Chem., 1996, 7, 217-232.

13 W. A. Howard, A. Bayomi, E. Natarajan, M. A. Aziza, O. ElAhmady, C. B. Grissom and F. G. West, Bioconjugate Chem., 1997, 8, 498-502.

14 J. D. Bagnato, A. L. Eilers, R. A. Horton and C. B. Grissom, J. Org. Chem., 2004, 69, 8987-8996.

15 S. Mundwiler, B. Spingler, P. Kurz, S. Kunze and R. Alberto, Chem. - Eur. J., 2005, 11, 4089-4095.

16 R. Mukherjee, E. G. Donnay, M. A. Radomski, C. Miller, D. A. Redfern, A. Gericke, D. S. Damron and N. E. Brasch, Chem. Commun., 2008, 3783-3785.

17 C. C. Smeltzer, M. J. Cannon, P. R. Pinson, J. D. Munger, F. G. West and C. B. Grissom, Org. Lett., 2001, 3, 799-801.

18 S. Kunze, F. Zobi, P. Kurz, B. Spingler and R. Alberto, Angew. Chem. Int. Edit., 2004, 43, 5025-5029.

19 P. Ruiz-Sanchez, S. Mundwiler, A. Medina-Molner, B. Spingler and R. Alberto, J. Organomet. Chem., 2007, 692, 1358-1362.

20 J. Wuerges, G. Garau, S. Geremia, S. N. Fedosov, T. E. Petersen and L. Randaccio, Proc. Natl. Acad. Sci. U. S. A., 2006, 103, 4386-4391.

21 M. Lee and C. B. Grissom, Org. Lett., 2009, 11, 2499-2502.

22 N. Viola-Villegas, A. E. Rabideau, M. Bartholoma, J. Zubieta and R. P. Doyle, J. Med. Chem., 2009, 52, 5253-5261.

23 P. Siega, J. Wuerges, F. Arena, E. Gianolio, S. N. Fedosov, R. Dreos, S. Geremia, S. Aime and L. Randaccio, Chem. Eur. J., 2009, 15, 7980-7989.

24 A. K. Petrus, A. R. Vortherms, T. J. Fairchild and R. P. Doyle, ChemMedChem, 2007, 2, 1717-1721.

25 C. H. Fazen, D. Valentin, T. J. Fairchild and R. P. Doyle, J. Med. Chem., 2011, 54, 8707-8711.

26 D. A. Collins and H. P. Hogenkamp, J. Nucl. Med., 1997, 38, 717-723.

27 J. Q. Yang, Y. Li, J. Lu and X. B. Wang, J. Radioanal. Nucl. Chem., 2005, 265, 467-472.

28 B. Spingler, S. Mundwiler, P. Ruiz-Sánchez, D. R. van Staveren and R. Alberto, Eur. J. Inorg. Chem., 2007, 2641-2647.

29 J. H. Matthews, Blood, 1997, 89, 4600-4607.

30 K. Zhou and F. Zelder, Angew. Chem., Int. Ed., 2010, 49, 5178-5180.

31 K. Zhou, R. M. Oetterli, H. Brandl, F. E. Lyatuu, W. Buckel and F. Zelder, ChemBioChem, 2012, 13, 2052-2055.

32 R. Waibel, H. Treichler, N. G. Schaefer, D. R. van Staveren, S. Mundwiler, S. Kunze, M. Kuenzi, R. Alberto, J. Nuesch, A. Knuth, H. Moch, R. Schibli and P. A. Schubiger, Cancer Res., 2008, 68, 2904-2911.

33 A. K. Petrus, D. G. Allis, R. P. Smith, T. J. Fairchild and R. P. Doyle, ChemMedChem, 2009, 4, 421-426.

34 A. K. Petrus, T. J. Fairchild and R. P. Doyle, Angew. Chem., Int. Ed., 2009, 48, 1022-1028.

35 S. M. Clardy, D. G. Allis, T. J. Fairchild and R. P. Doyle, Expert Opin. Drug Delivery, 2010, 8, 127-140.

36 D. L. Lildballe, E. Mutti, H. Birn and E. Nexø, PLoS One, 2012, 7, e46657. 
37 T. C. Johnstone, G. Y. Park and S. J. Lippard, Anticancer Res., 2014, 34, 471-476.

38 D. Wang and S. J. Lippard, Nat. Rev. Drug Discovery, 2005, 4, 307-320.

39 D. A. Dows, A. Haim and W. K. Wilmarth, J. Inorg. Nucl. Chem., 1961, 21, 33-37.

40 P. Ruiz-Sanchez, S. Mundwiler, B. Spingler, N. R. Buan, J. C. Escalante-Semerena and R. Alberto, JBIC, J. Biol. Inorg. Chem., 2008, 13, 335-347.

41 F. H. Niesen, H. Berglund and M. Vedadi, Nat. Protoc., 2007, 2, 2212-2221.

42 M. T. Q. Tran, E. Furger and R. Alberto, Org. Biomol. Chem., 2013, 11, 3247-3254.

43 N. P. Johnson, J. D. Hoeschele, N. B. Kuemmerle, W. E. Masker and R. O. Rahn, Chem. - Biol. Interact., 1978, 23, 267-271.

44 N. P. Johnson, J. D. Hoeschele and R. O. Rahn, Chem. - Biol. Interact., 1980, 30, 151-169.

45 C. A. Hall, W. H. Hitzig, P. D. Green and J. A. Begley, Blood, 1979, 53, 251-263.

46 N. Berliner and L. E. Rosenberg, Metabolism, 1981, 30, 230-236.

47 M. Ramasamy, D. H. Alpers, C. Tiruppathi and B. Seetharam, Am. J. Physiol., 1989, 257, G791-797.
48 K. S. Ramanujam, S. Seetharam, M. Ramasamy and B. Seetharam, Am. J. Physiol., 1991, 260, G416-422.

49 G. R. McLean, E. V. Quadros, S. P. Rothenberg, A. C. Morgan, J. W. Schrader and H. J. Ziltener, Blood, 1997, 89, 235-242.

50 W. H. Hitzig, U. Dohmann, H. J. Pluss and D. Vischer, J. Pediatr., 1974, 85, 622-628.

51 I. Mellman, H. F. Willard, P. Youngdahl-Turner and L. E. Rosenberg, J. Biol. Chem., 1979, 254, 11847-11853.

52 P. Ruiz-Sanchez, C. Konig, S. Ferrari and R. Alberto, JBIC, J. Biol. Inorg. Chem., 2011, 16, 33-44.

53 H. S. Tastesen, J. B. Holm, J. Moller, K. A. Poulsen, C. Moller, S. Sturup, E. K. Hoffmann and I. H. Lambert, Cell. Physiol. Biochem., 2010, 26, 809-820.

54 J.-F. Pons, J.-L. Fauch''re, F. Lamaty, A. Molla and R. Lazaro, Eur. J. Org. Chem., 1998, 853-859.

55 R. Alberto, R. Schibli, A. Egli, P. August Schubiger, W. A. Herrmann, G. Artus, U. Abram and T. A. Kaden, J. Organomet. Chem., 1995, 493, 119-127.

56 A. Stichelberger, Nucl. Med. Biol., 2003, 30, 465-470.

57 M. Q. Tran, Y. Nygren, C. Lundin, P. Naredi and E. Bjorn, Anal. Biochem., 2010, 396, 76-82. 